\title{
INVESTIGATING THE EFFECTS OF HEAVY METALS IN THE WASTE LEACHATE ON THE GROUNDWATER QUALITY NEAR THE LANDFILL (CASE STUDY: LANDFILL OF SARAVAN, RASHT)
}

F. Geravand ${ }^{1, *}$, M. Momenpour ${ }^{1}$, M. Derakhshan Houreh ${ }^{1}$, S. Aghileh Hejazi Kamsari ${ }^{2}$

${ }^{1} \mathrm{PhD}$ student of environmental pollution, Tonekabon Branch, Islamic Azad University, Tonekabon Iran

${ }^{2}$ Master of science, natural resources engineering, the environment and biodiversity

Published online: 15 February 2017

\begin{abstract}
The main and fundamental scientific reason of scientific community attention to the issue of leachate pollution and its treatment is the possible danger of contamination of water, soil and to some extent air. The reason is that the leachate of landfill in fact is acomplex waste withhigh pollution. Today, in our country, especially in northern areas due to high groundwater levels, the problem of waste disposal and the effects of their leachate entering alluvial groundwater and aquifer contamination downstream based on hydrodynamic thickness in the movement of water is highly regarded andentering a considerable amount of pollution (nitrates, heavy metals, etc.) to underground water sources used for drinking and agriculture, in the long term become a social problem. Saravan landfill is located on $15 \mathrm{~km}$ road Rasht of to Tehran is like a black spot in the in the green Hyrcanian forest and receives more than 500 tons of waste daily from provinces cities,particularly Rasht which with no environmental assessment for selected waste disposal, waste disposal is inadequate in Saravan and because of evaporation, fermentation and decomposition of the waste and leachate percolation into the soil and water resources it is associated with high pollution and unleashed leachate river in the heart of nature and based on the ranking of Index criteria it is unacceptable. In this study, sampling was conducted in 2 upstream wells, 3 downstream wells of Saravan landfill then the samples were analyzed by atomic absorption.
\end{abstract}

\footnotetext{
Author Correspondence, e-mail: Gravand92@gmail.com

doi: http://dx.doi.org/10.4314/jfas.v9i1s.707
} 
The results indicate the presence of heavy metals (chromium - lead - zinc -iron - manganese) in water of downstream wells of the landfill compared to upstream wells and the control wells or in other words, it was significantly more than the control and upstream wells and the average concentrations of $\mathrm{Pb}, \mathrm{Cr}, \mathrm{MN}$, Fe higher than drinking water standards and the mean concentration of $\mathrm{MN}$ and $\mathrm{Cr}$ in the research water wells was more than standard water for irrigation and agricultural. It shows the leachate percolation into soil and ground water that has been polluted the nearby water of the landfill.

Keywords: Groundwater, Landfill, Leachate, Heavy Metals, Saravan

\section{1-INTRODUCTION}

Each year, the amount of solid waste production is on the rise. The increases of the amount waste as a result of population growth, is lead to changing consumption patterns and lifestyle. The infiltration of rainwater into the waste producesleachate.Leachate waste usually has a high concentration of heavy metals that create serious risks for the environment and health of humans. As a result the decomposition of solid waste and leachate composition will vary over time. The features leachate from a landfill to another location significantly changes. Contamination occurs when large amounts of material enter into the natural environment and hasinversion effects on nature. The pollution of underground water in underdeveloped or developing countries which the industrial hazardous waste, is landfilled at the same time of municipal solid waste, , are seen in many parts of the world [1].

The issue of groundwater contamination due to leachate percolation is one of the main difficulties of landfills. Leachate is defined as seepage liquid from waste and containing suspended and dissolved solids which contains material derived from waste and liquid of surface drainage, precipitation, and groundwater and springs [3]. Leachate can contaminate surface water and groundwater, which issue of groundwater contamination due to leachate percolation is one of the biggest problems of landfills [4]. Heavy metals such as lead, cadmium and chromium, and zinc refer to those chemical elements that have a density of more than 3 to 5 grams per cubic centimeters [5]. These elements are one of the most important environmental pollutants. The properties of these metals can that be noted is stability whichcannot be decomposed in nature like most organic material through chemical and biological processes. One important result of this stability and concentration of heavy metals in food or tissues of organisms is the food they use [6]. The amount of water in the landfills isestimated 1 to 0.40 of annual precipitation which an average is 0.37 liters per second per hectare. The water leaking landfill is dependent on the amount, extent and manner 
of rainfall, hydraulic conductivity, soil cover, soil surface evaporation, and ice and snow melting.

A general study by the World Health Organization confirms the fact that lack of attention to the collection and proper disposal of solid waste, creates about 32 environmental problems that dealing with them simply is not possible over time [7].This issue even in developed countries costs a lot of expenses due to environmental degradation and pollution. Mass contamination in the ground water caused by the landfill leachate in Borden in Canada caused pollution of an area about $700 \mathrm{~m}$ length, and $600 \mathrm{~m}$ width and 20 meters depth. Also mass contamination caused by the landfill in Bavaroan in Germany, in the form of narrow strip (length $3000 \mathrm{~m}$ ) was due to soil contamination. Denmark landfill pollution in areas length 40 meters and a maximum depth of 20 meters has been contaminated underground aquifer which decontamination in addition to the prohibitive cost, will take several years [7]. Such problems are why the issue of treatment of leachate is of high importance.

Heavy metals such as cadmium, lead and arsenic cannot be deteriorated [8]. Most of these metals are not only essential for biological life, but they have high toxicity. One of the fundamental problems associated with heavy metals is that they are not metabolized in the body [9]. In fact, heavy metals after entering the body are not deposited, but also are accumulated in the tissue of the body, such as fat, muscles, bones and joints which is the causes of diseases and complications in the body. In general, the effects of heavy metals on the human body are neurological disorders, cancer and in severe cases death. On one hand the accumulative feature of heavy metals in plants and entering the food chain will double their risk [10].

Saravan site is a dark spot in green nature of north which with no environmental assessment for selected waste disposal, waste disposal in Saravan is inappropriate and because of evaporation, fermentation and decomposition of the waste and leachate percolation into the soil and water resources is associated with a lot of pollution and based on the ranking indices criteria are in the unacceptable class. Therefore, this essay investigated the groundwater pollution by heavy metals in leachate of Saravan due to the importance of environmental and health pollution of underground water of Saravan landfill site by ions, particularly heavy metals (cadmium, lead, zinc, cobalt, mercury, arsenic, etc.) in leachate because of unsystematic waste disposal and according to the principles of natural biological physiological conditions, climate and topography and soil conditions to prevent the entry of the annual 70 million liters of leachate to groundwater and surface water and presented somerecommendations. 


\section{2- MATERIALS AND METHODS}

Rasht waste was transferred to the region of Saravan forest in 1983. The site is located in 15 to 20 kilometers away from Rasht, which about 500 tons of waste daily is piled inappropriately. This place is receptive of the waste the cities of Rasht, Fooman, Shaft, Somesara, Khoshkbijari, Lasht Nesha, Koochesfahan and a part of Anzali which the share of Rasht is about 450 tons of waste per day [11].Saravan waste leachate is entered into Anzali lagoon byZarjoob and Pir Bazar rivers. In Somesara the temporary place of waste depot was located in the margin of Masooleh River which after collecting was transferred to Saravan. It should be noted that currently about $90 \%$ of waste transported to Saravanl and fill is produced in Rasht which the average moisture is 0.063 and an average density is 38 kilograms per cubic meter. Therefore the leachate flow occurs due to high humidity and high rainfall in the region.

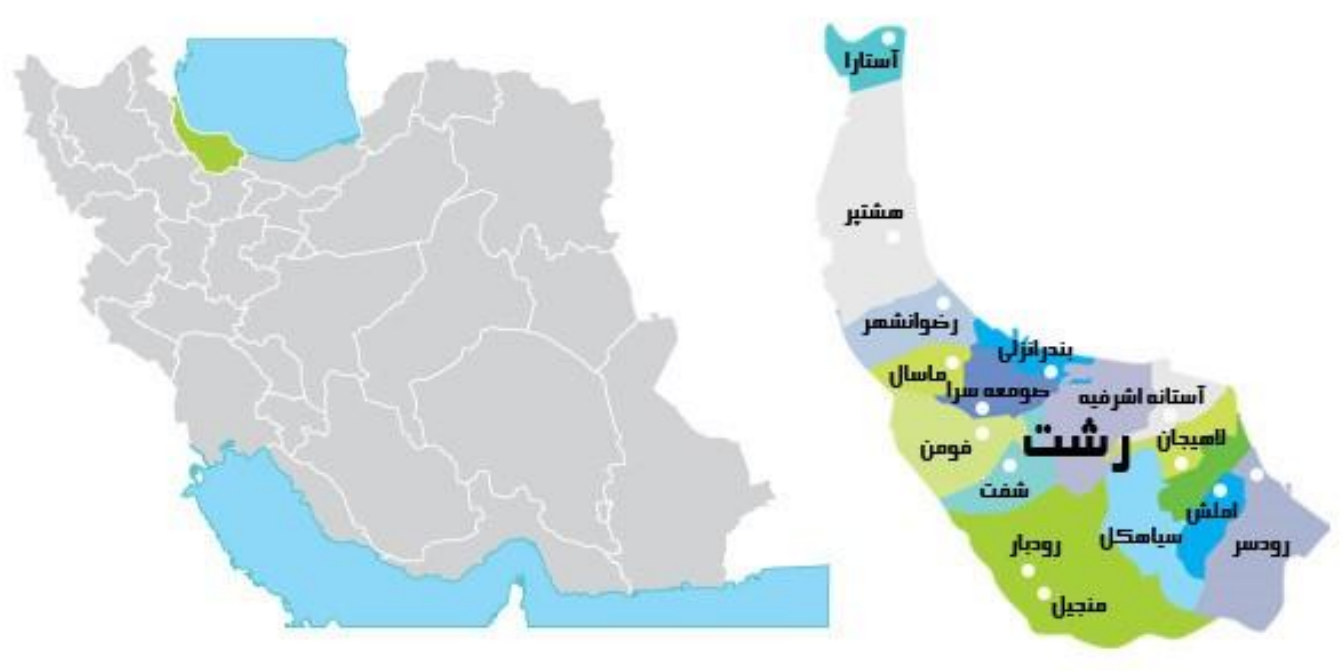

Fig.1. Location of Gilan Province 

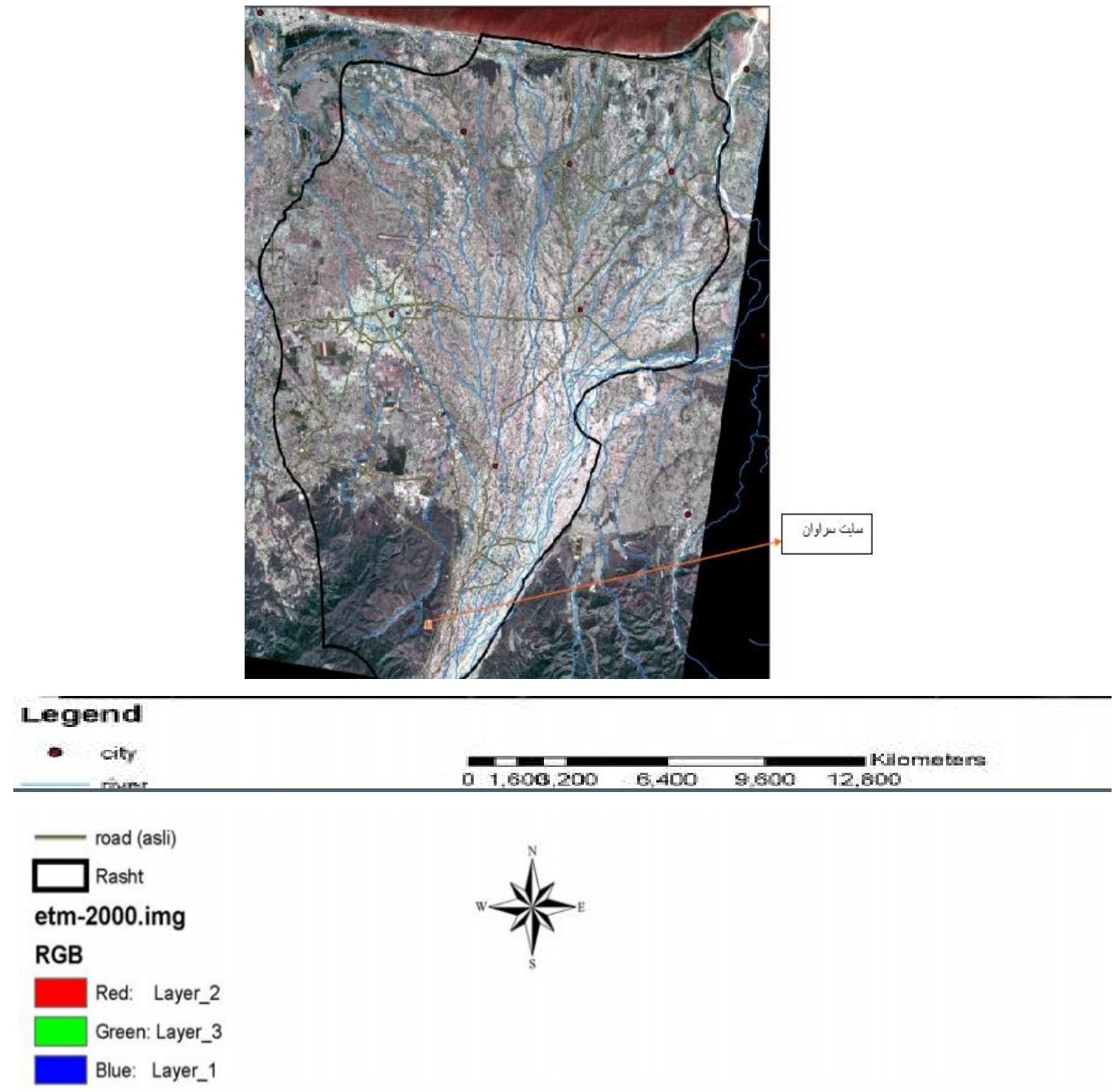

Fig.2. Satellite image of Saravan

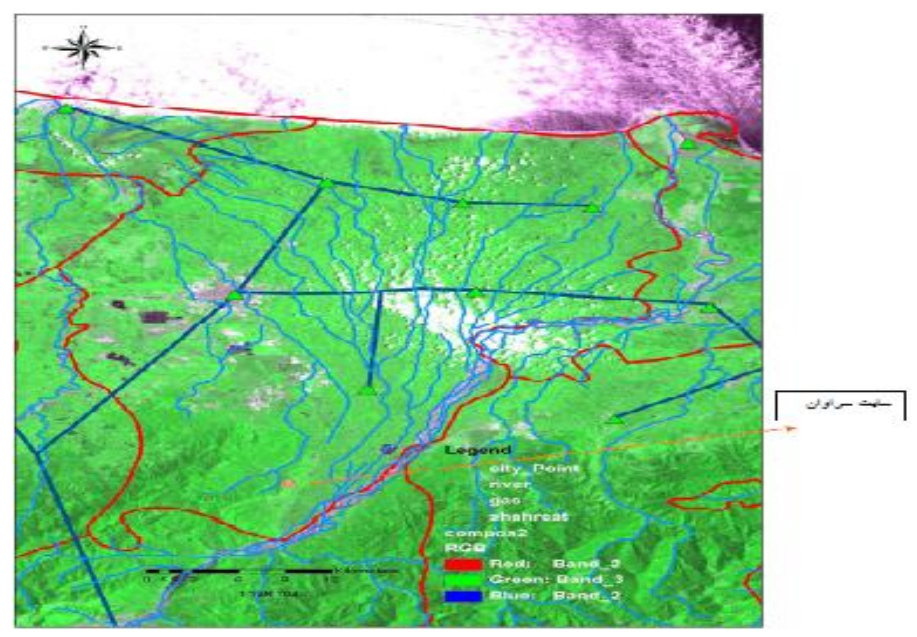

Fig.3. location of Saravan Site in the satellite image of Rasht city with location of rivers, main cities, main gas line and the city border 


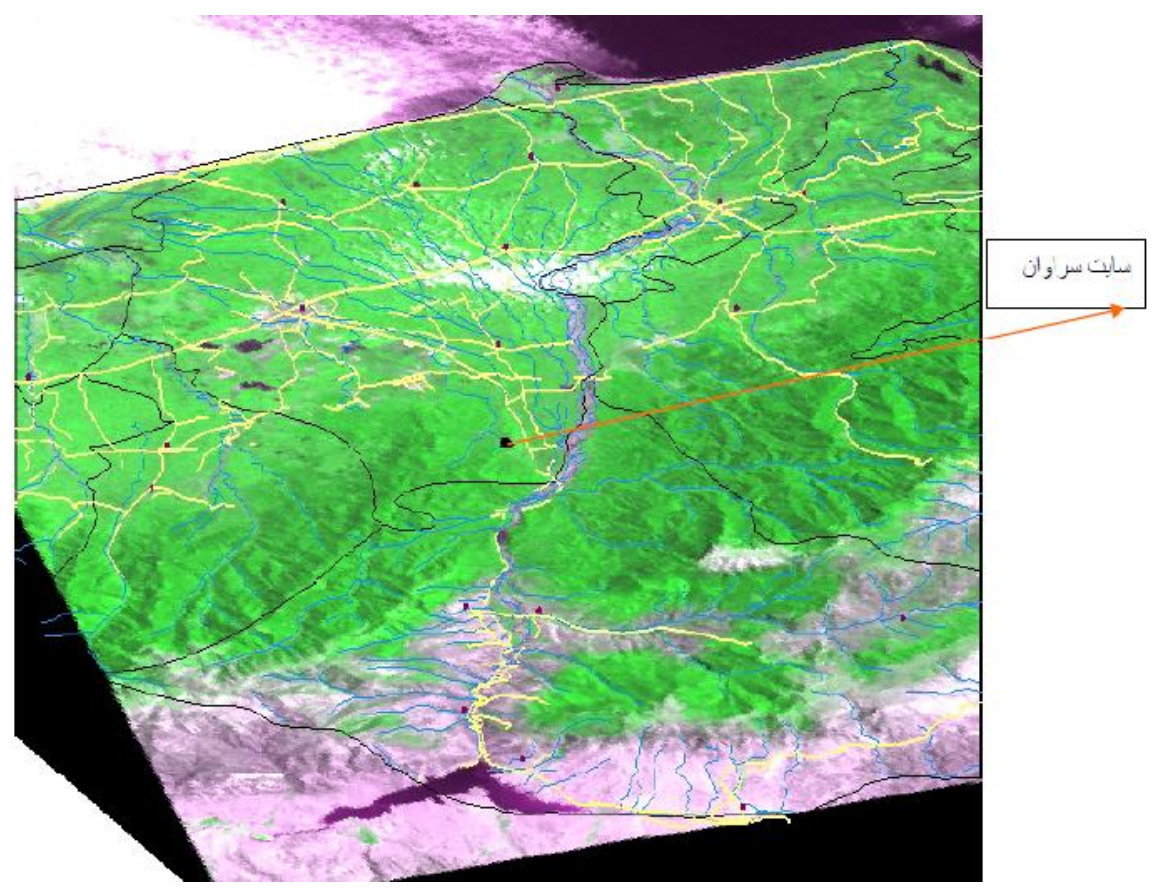

Fig.4. Location of Saravan Site on a satellite image of the Rasht city (panoramic image) with location of rivers, major cities, the city border and Manjil Dam

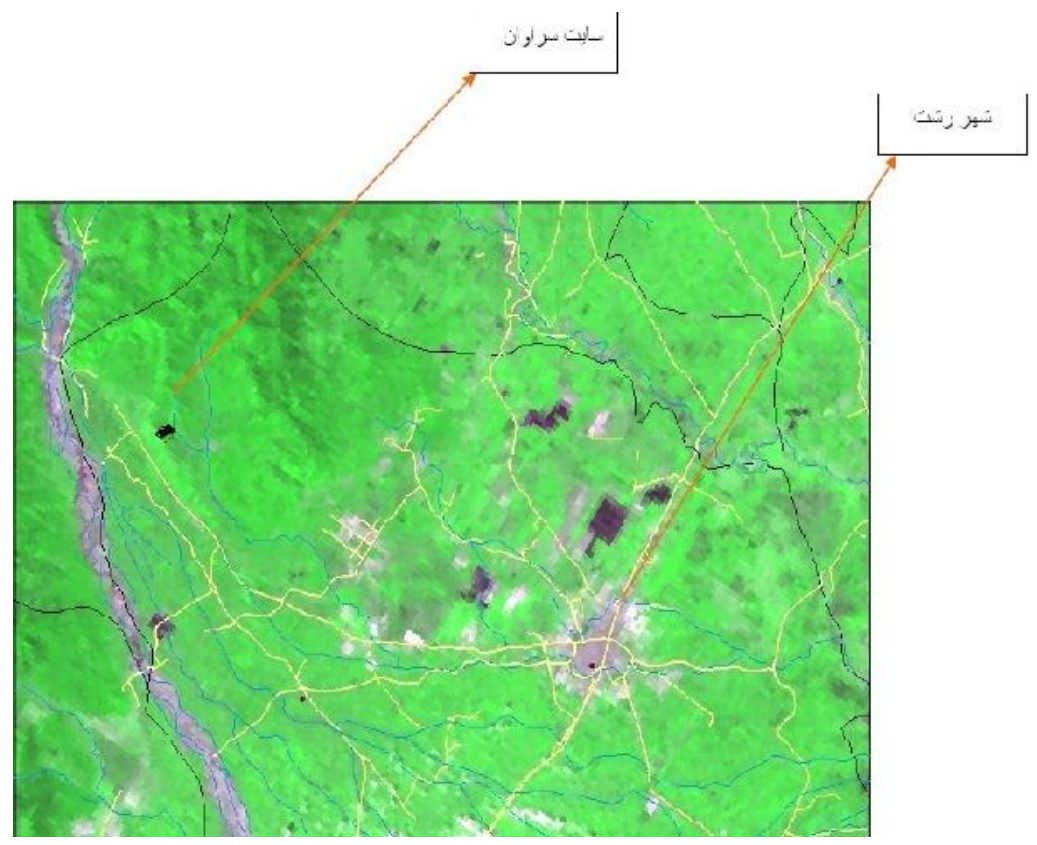

Fig.4. Location of Saravan Site on a satellite image of the Rasht city (vertical image) with location of rivers, Rasht and the road 


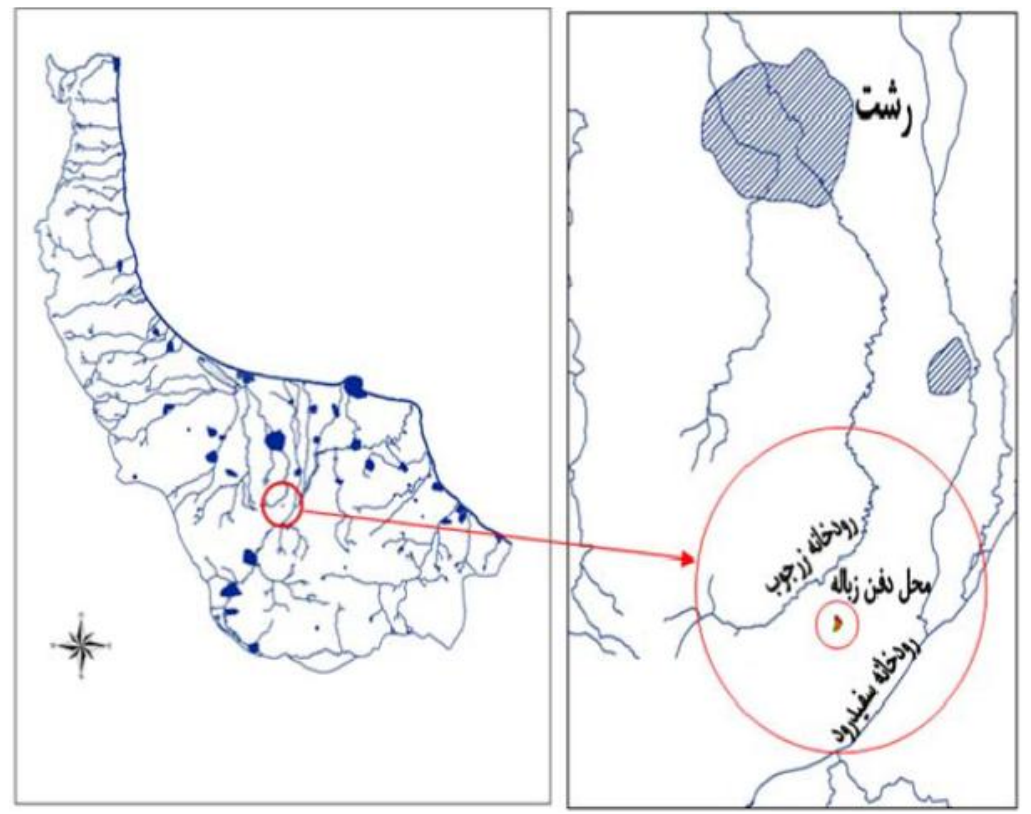

Fig.6. Location of the study area and waterways available

Saravan waste leachate is entered into Anzali lagoon by Zarjoob and Pir Bazar rivers. Saravan landfill distance is about $2 \mathrm{~km}$ from the Zarjoob River and $2.5 \mathrm{~km}$ from the SEFID River, Saravan landfill slope is $15 \%$ and the annual rainfall is over $1200 \mathrm{~mm}$.

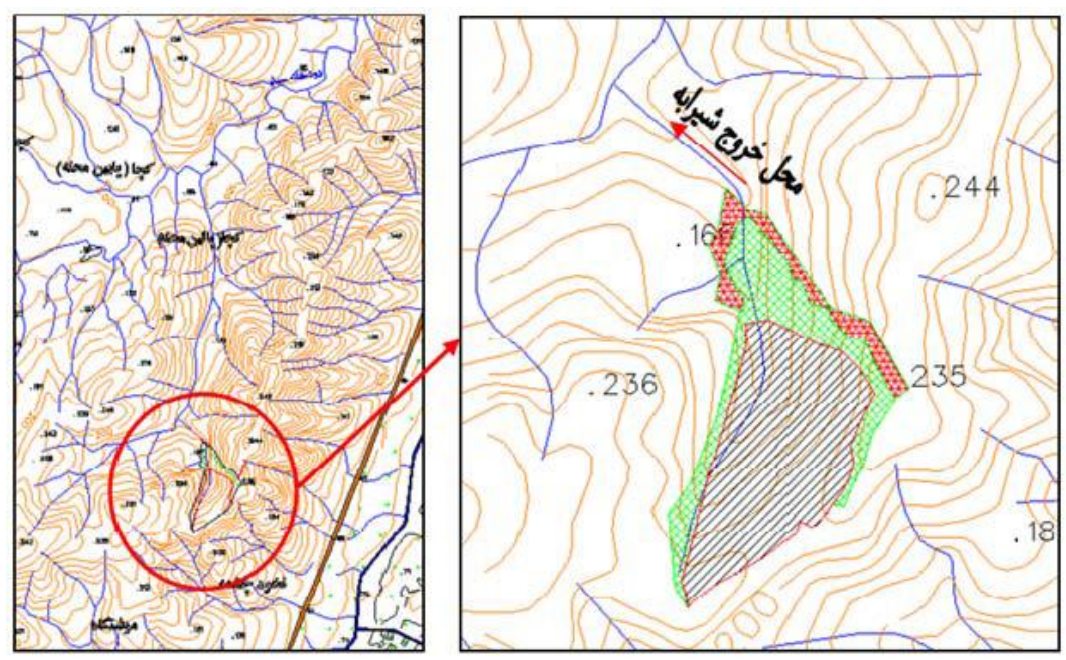

Fig.7. Topography of landfill leachate and the final output mechanisms 


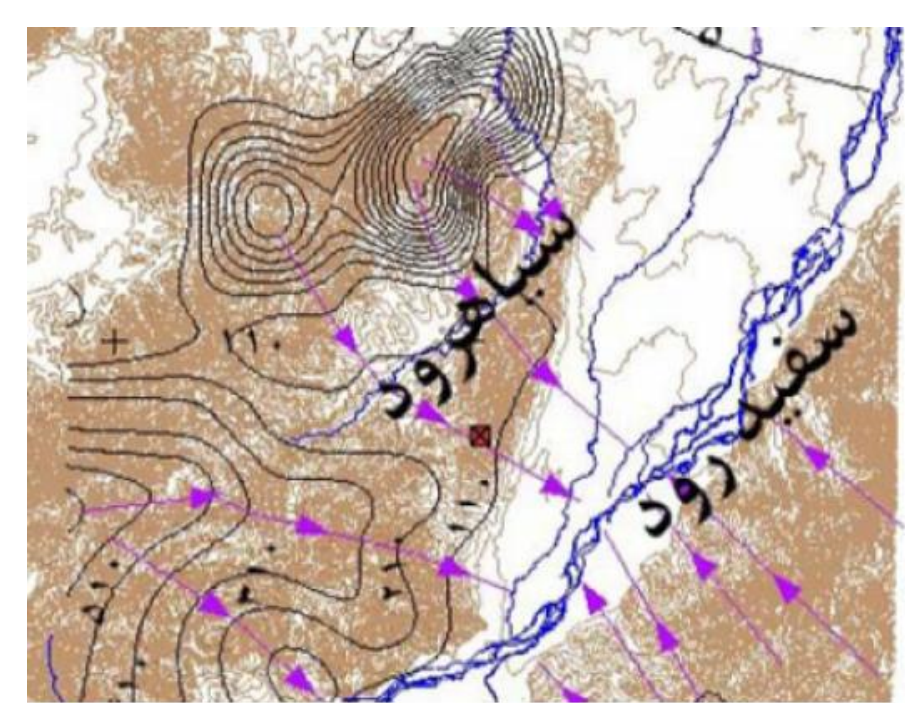

Fig.8. groundwater flow direction in the region of Saravan landfill

In terms of geology, the area has two different formations: 1-Loess structure within the alluvial bed of Sefid River 2-Hard carbonate Formation of Saravan heights and Imam Hashim, which Saravan landfill is, located in hard carbonate formations.

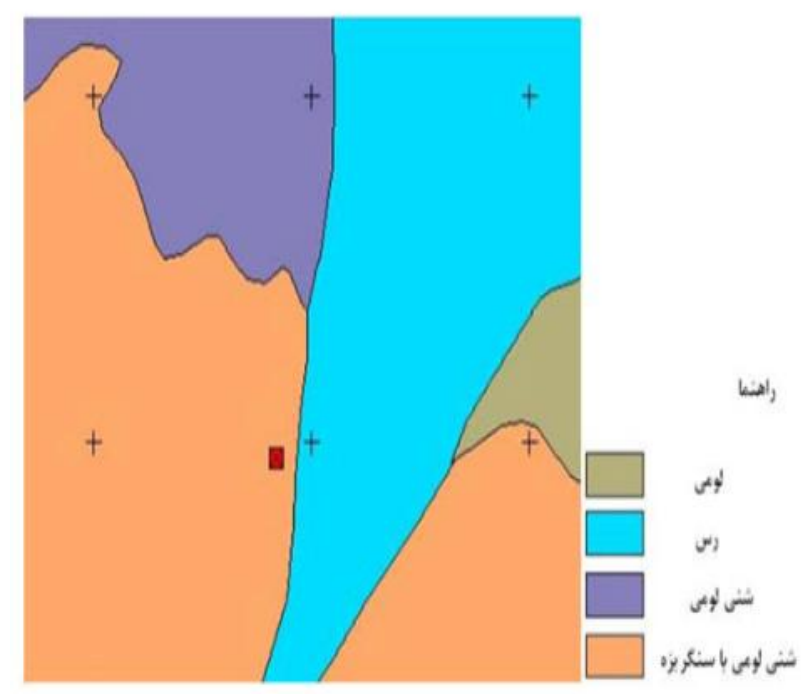

Fig.9. soil map of Saravan landfill

Due to the high level of underground water the groundwater contamination in the area is possible and because the direction of groundwater was toward the Sefid River and the region slope is in this direction and according to the type of soil that is sandy loam with pebbles and given the amount of leachate infiltration and high pollution of leachate that has been proven by experiments, there is the possibility of aquifers contamination. Therefore, this research is trying to investigate the quality of wells around the landfill, especially in terms of heavy metals (the number of wells are 16 which 8 wells with depths greater than 40 meters and 3 
wells are also used to drinking, out of three drinking water wells 2 wells are at downstream of the landfill and one is at upstream) and qualitative parameters of heavy metals and landfill leachate wells studied in four seasons by using various test and washable plastic container with sulfuric acid to prevent the growth of bacteria sampled. Water samples were filtered for chemical analysis of heavy metals, first by a filter of 0.45 micron. Then the concentrated nitric acid was added and was sent to the laboratory for analysis and it was measured by ICP-MS method. To transfer water samples to determine the concentration of heavy metals, the $50 \mathrm{cc}$ polyethylene bottles were used. And to protect water samples to measure heavy metals 1.5 $\mathrm{mL}$ of concentrated nitric acid was added to per liter of sample to sample $\mathrm{PH}$ is less than 2 , and the samples to be representative of underground water, sampling was carried out for 3 to 5 minutes and at a rate almost three times the volume of water supply pipes from wells and each of the samples were measured using chemical methods to measure physical characteristics of groundwater (heavy metals were analyzed using atomic absorption). And finally due to the high concentration of contaminants (heavy metals) in the wells downstream it was determined that in downstream wells compared to upstream wells and control and standards wells it can be seen that the influence of waste landfill leachate can contaminate groundwater wells adjacent to landfill area. And the results of sample analysis in SPSS Software are presented in the table below.

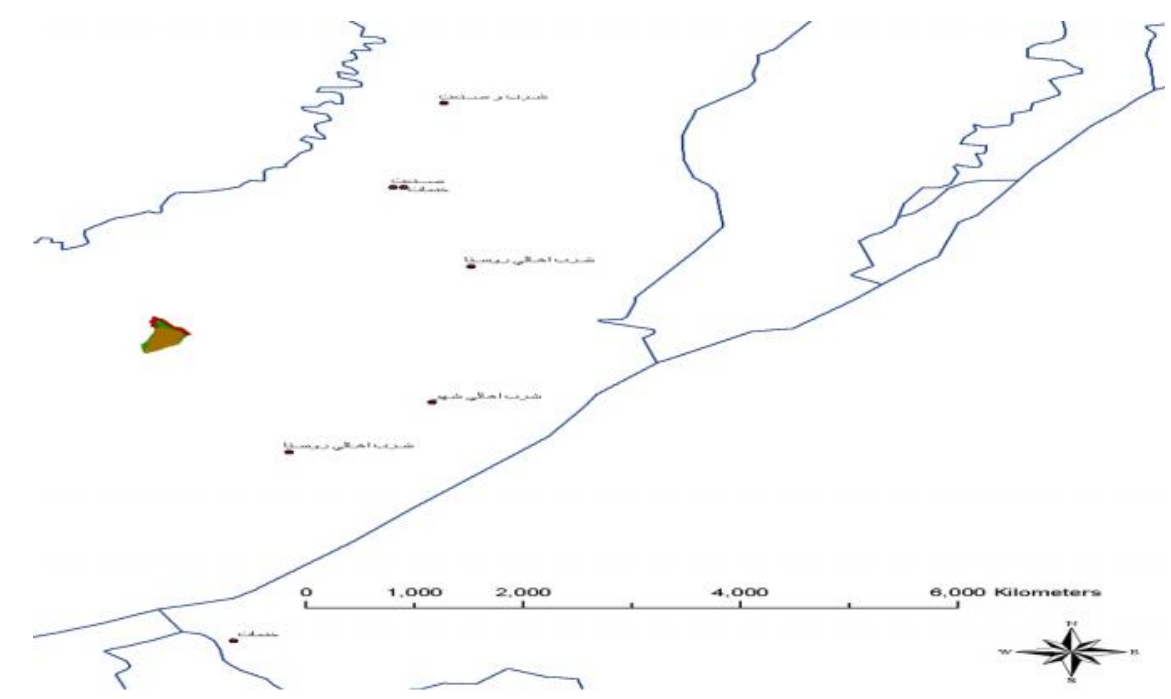

Fig.10. the location of the wells with a depth of over 40 meters in Saravan region 
Table 1. Iran and WHO standard for permitted maximum of heavy metals in drinking water

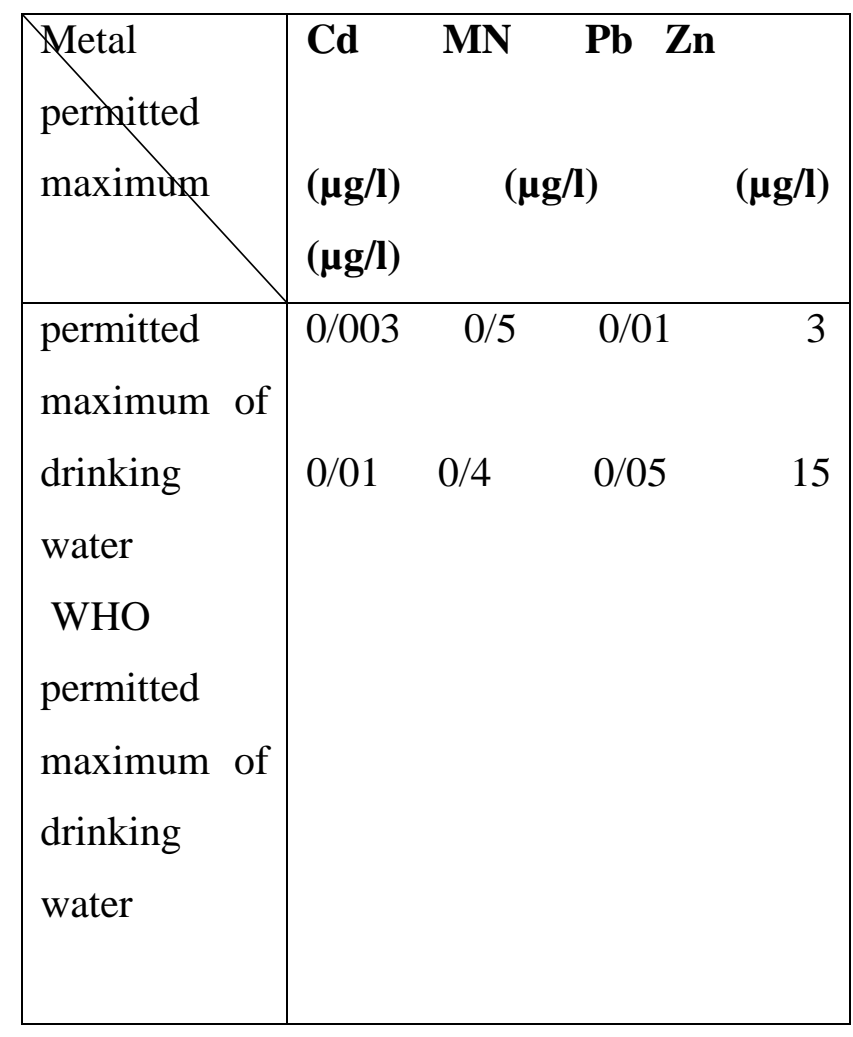


Table 2. Chemical analysis of water quality of sampled wells and waste leachate and relevant standards in terms of heavy metals

\begin{tabular}{|c|c|c|c|c|c|c|c|c|c|}
\hline $\begin{array}{l}\text { Ro } \\
\text { W }\end{array}$ & $\begin{array}{l}\text { Heav } \\
\mathrm{y} \\
\text { metal }\end{array}$ & $\begin{array}{l}\text { Well } 1 \\
\text { (ShahidBeh } \\
\text { eshti } \\
\text { Complex) } \\
\text { downstream }\end{array}$ & $\begin{array}{l}\text { Well } 2 \\
\text { (Golsork) } \\
\text { downstre } \\
\text { am }\end{array}$ & $\begin{array}{l}\text { Well } 3 \\
\text { (Gozarkh } \\
\text { an Amu) } \\
\text { upstream }\end{array}$ & $\begin{array}{l}\text { Mean } \\
\text { of } \\
\text { (sample } \\
\text { d wells) }\end{array}$ & $\begin{array}{l}\text { Co } \\
\text { ntro } \\
1 \\
\text { wel } \\
1\end{array}$ & $\begin{array}{l}\text { leach } \\
\text { ate }\end{array}$ & $\begin{array}{l}\text { Drinki } \\
\text { ng } \\
\text { water } \\
\text { standar } \\
\text { d }\end{array}$ & $\begin{array}{l}\text { Agri } \\
\text { cult } \\
\text { ural } \\
\text { stan } \\
\text { dard }\end{array}$ \\
\hline 1 & $\begin{array}{l}\mathrm{Cr}( \\
\mathrm{mg} / \mathrm{l})\end{array}$ & $0 / 42$ & $0 / 17$ & $0 / 09$ & $0 / 22$ & $\begin{array}{l}/ 05 \\
0\end{array}$ & $0 / 13$ & $0 / 1$ & $0 / 1$ \\
\hline 2 & $\begin{array}{l}\mathrm{Cd} \\
(\mathrm{mg} / \mathrm{l} \\
)\end{array}$ & ND & ND & ND & ND & ND & $0 / 08$ & $0 / 005$ & $\begin{array}{l}/ 001 \\
0\end{array}$ \\
\hline 3 & $\begin{array}{l}\mathrm{pb} \\
(\mathrm{mg} / \mathrm{l} \\
)\end{array}$ & $0 / 28$ & $0 / 16$ & $0 / 07$ & $0 / 17$ & $\begin{array}{l}/ 02 \\
0\end{array}$ & $0 / 91$ & 0 & 5 \\
\hline 4 & $\begin{array}{l}\mathrm{Zn} \\
\mathrm{mg} / \mathrm{l})\end{array}$ & $0 / 488$ & $0 / 231$ & $0 / 098$ & $0 / 27$ & $\begin{array}{l}196 \\
0\end{array}$ & $1 / 8$ & 5 & 2 \\
\hline 5 & $\begin{array}{l}\mathrm{Fe}( \\
\mathrm{mg} / \mathrm{l})\end{array}$ & $0 / 79$ & $0 / 291$ & $0 / 16$ & $0 / 41$ & $\begin{array}{l}195 \\
0\end{array}$ & $4 / 66$ & $0 / 3$ & 5 \\
\hline 6 & $\begin{array}{l}\mathrm{Mn} \\
(\mathrm{mg} / \mathrm{l} \\
)\end{array}$ & $3 / 64$ & $0 / 005$ & $0 / 14$ & $1 / 01$ & $\begin{array}{l}005 \\
0 /\end{array}$ & $3 / 64$ & $0 / 5$ & $0 / 2$ \\
\hline
\end{tabular}

\section{3- DISCUSSION AND RESULTS}

After sampling and conducting related tests the results of tests are analyzed by SPSS statistical software, it analyzes the raw data by descriptive and inferential analysis (regression) and the results are as follows:

The average concentration of chromium in the sampled wells was $0.226 \mathrm{mg}$ and in control wells was 0.053 milligrams per liter which statistically there is a significant difference between the two groups $(\mathrm{P}<0.05)$ and the highest amount of $\mathrm{Cr}$ in the studied wells was 0.42 $\mathrm{mg}$ in well No.1 and the lowest was $0.09 \mathrm{mg}$ per liter in the wellNo.3. The recommended EPA for standard limit for chromium in drinking water and irrigation is 0.1 milligrams per 
liter which in terms of statistical comparison with the standards of drinking water and irrigation, there was a significant difference $(\mathrm{P}<0.05)$ and water of wells is not suitable for drinking and irrigation.

The average level of lead in the studied wells was $0.17 \mathrm{mg}$ per liter and in control well was $0.02 \mathrm{mg}$ per liter which statistically there was a significant difference $(\mathrm{P}<0.05)$ (According to the EPA standard levels of lead in drinking water is determined zero, and for agricultural irrigation and $5 \mathrm{mg}$ per liter and statistically there was a significant difference between drinking and irrigation water $(\mathrm{P}<0.05)$ therefore, the parameters of lead to drinking water wells was not suitable, but it has no problem for irrigation and agriculture.

The mean of zinc in sampled wells was $0.272 \mathrm{mg}$ per liter and in control group was $0.096 \mathrm{mg}$ per liter thus statistically there was a significant difference between two groups $(\mathrm{P}<0.05)$, the highest amount of zinc in sampled wells was $0.488 \mathrm{mg}$ per liter in well No.1 and the lowest amount of zinc in sampled wells was $0.098 \mathrm{mg}$ per liter in well No.3.

The recommended standard (EPA) of zinc in drinking water is $5 \mathrm{mg}$ per liter and it is $2 \mathrm{mg}$ for irrigation and agriculture and statistically there was a significant difference between standards of drinking and irrigation water $(\mathrm{P}<0.05)$, in other words that is significantly less than the standards for drinking water and irrigation thus well water has no limitation for drinking and irrigation.

The mean of iron in sampled wells was $0.413 \mathrm{mg}$ per liter and in control group was $0.095 \mathrm{mg}$ per liter thus statistically there was a significant difference between two groups $(\mathrm{P}<0.05)$, the highest amount of iron in sampled wells was $0.291 \mathrm{mg}$ per liter in well No.2 and the lowest amount of iron in sampled wells was $0.16 \mathrm{mg}$ per liter in well No.3. The EPA standard limit of iron in drinking water is $0.3 \mathrm{mg}$ per liter and it is $5 \mathrm{mg}$ for irrigation. Thuswell No.1 in terms of standard iron is not suitable for drinking but the water of all under study wells in terms of iron parameter has no problem for irrigation and agricultural.

The mean of manganese in sampled wells was $1.01 \mathrm{mg}$ per liter and in control group was $0.005 \mathrm{mg}$ per liter thus statistically there was a significant difference between two groups $(\mathrm{P}<$ 0.05), the highest amount of manganese in sampled wells was $1.83 \mathrm{mg}$ per liter in well No.1 and the lowest amount of manganese in sampled wells was $0.14 \mathrm{mg}$ per liter in well No.3.The EPA standard limit of MN in drinking water is $0.05 \mathrm{mg}$ per liter and it is $0.2 \mathrm{mg}$ for irrigation which statistically there was a significant difference with drinking water standard $(\mathrm{P}<$ 0.05), well No.1 \& No.2 in term of drinking water standard is not suitable and well No.1 \& No. 2 in term of irrigation water standard is limited. 
The comparison of concentrations of heavy metals waste disposal leachate with the Environmental Protection Agency's standard for agriculture and irrigation suggests that the concentration of chromium is 1.4 times, cadmium 8.5 times and manganese 20 times higher than the limit and Iron, zinc and only lead and iron are slightly less than the limit. In term of concentration zinc has the highest concentration $(1.8 \mathrm{mg}$ per liter) and cadmium has the lowest concentration $(0.085 \mathrm{mg}$ per liter)that in term of concentration respectively $\mathrm{Fe}>\mathrm{Mn}>$ $\mathrm{Zn}>\mathrm{Cr}>\mathrm{Pb}>\mathrm{Cd}$ are available in leachate.

If the concentration of heavy metals in waste disposal is compared to standard EPA Iran for agriculture and irrigationit can be seen that the cadmium concentration is exceeded 5 times more than the limit and chromium, lead, zinc, and iron are below the permissible limit and manganese is over the limit.

The comparison of the results of this research show that some common chemical parameters in water wells were exceeded and groundwater pollution, especially in areas close to landfill are found to be substantial, and the comparison of mean of wells water with a fixed number in cases of Mn, Cd, Cr has significantly decreased $(\mathrm{P}<0.05)$.

\section{4- CONCLUSION}

In total, results showed that the mean of concentration of the studied parameters such as heavy metals (chromium-iron-manganese - lead- zinc, manganese) in study wells close to landfill compared to control well water and upstream wells had significant differences or it is significantly more than control and upstream wells and the mean of concentration of $\mathrm{Pb}, \mathrm{Cr}$, $\mathrm{Mn}, \mathrm{Fe}$ is more than the standard of drinking water and the mean of concentration of Mn and $\mathrm{Cr}$ in water of under study wells for irrigation and agriculture and in general the concentration of heavy metals in wells adjacent to landfill compared to the control and upstream wells of landfill was higher which represents the leachate percolation into soil and ground water that has polluted the nearby water of landfill.

\section{5- RECOMMENDATIONS}

According to daily burial of 500 tons of waste and landfill expansion in recent years, an area of about 2 hectares per year is needed. The study based on land use planning science showed that 20 hectares of land on the western side of Saravan landfill, in order to place the landfill design standards to be applied landfill waste for the next 10 years. During this time it is necessary that the unhealthy waste disposal site with high contamination isconsidered and managed thus the cleanup and recycling of current location is emphasized; even if the waste 
discharge spaces available for the current landfill is not isolated,the pollution of surface and groundwater and air pollution due to the needs of landfill gas will continue until at least next 15 years. In addition, it is necessary for the discharge of waste other places outside the forest and by the standards of landfill sites on the basis of assessment and land use with environmental assessment (EIA) is selected and prepared.

Other:

- Separation of domestic, industrial and commercial waste landfill

- Implementation of health waste buried in landfills

- Avoid creating deep trenches covering the waste with soil, after the burial

- Using hydraulic protective layer, such as clay to prevent leakage of leachate and rain infiltration

- Embedded layer to a depth of 2 meters of silt and clay in areas where the ground water level is high.

- Creating the buffer around water sources and health control

- Following principles and standards with bed covering

- Disinfection of wells with contamination possibilities

- According to the villagers' awareness of potential problems that cause non-fulfillment of the promises of officials based on the transfer of landfill, they are willing for necessary cooperation and partnerships to take action in this regard with officials

- Following the successful experiences of other cities such as Isfahan, Shiraz and Mashhad regarding the collection and transportation of garbage from other towns and villages in the region of Saravan

- In order to prevent water pollution, landfill leachate is collected and treated before being discharged into water sources [12].

- Isolation of new proposed landfill area:There are several methods for this purpose that one of these methods is the use of geomembrane. This material can be used as landfill base lining and absorbing pollutants into groundwater therefore, geomembrane can be used in order to build the collection and treatment of leachate and the cost is low.

- Changing the landfill into a sanitary and principled landfill

- Offering a recycling and moving (mobile) compost at the site for landfill cleanup

- A particular place should be considered and isolated for waste disposal in landfill

- It is necessary to prevent environmental pollution after the installation of leachate treatment,the discharge of treated leachate should be continuously monitored. 


\section{6- REFERENCES}

1- Bahrami et al, The effect of Darab landfill pollution of groundwater, Journal of Engineering Geology and Environment, Spring 2015, Title, Issue 95, Page 151 -156

2- Badv, K., 2002- Leachate migration from URMIA landfill site, IRAN, and its effect on the quality of the surrounding soil and groundwater

3- Emadi, Seyed Mehdi; Investigating the contamination of groundwater by leachate of waste entering and ways to control it (Semeskandeh Surrey) Management and Planning Organization of Mazandaran, 2004

4- Omrani, Ghasemali; Solid waste; First Edition, Tehran, Islamic Azad University, 1994.

5- Masterson w, slowink I. Chemical principles. Fifth edition; 1981 .pp (317-330).

6- Peetty G. Irrigation with reclaimed municipal wastewater a guidance manual. University of California: California stat water resources control board 1998; PP (32),(13-1),(13-2). Annual Conference of the Canadian Society for Civil Engineering JTJU.

7- Ward, M., Bitton, G. \& Townsend, T., 2005- Heavy metal binding capacity (HMBC) of landfill leachates. Chemosphere 60: 206-215, municipal solid waste

8- Rejayi, Q. Pour Khabaz and HesariMotlagh. S (2011) Health risk assessment of heavy metals Aliabad Katul groundwater resources ", Journal of Medical Science, University of North Khorasan. Volume 4, Number 2, pp 155-162

9- Hadizadeh, H. Bakhshi A, AmelBesharati, J and Jafarzadeh, F (2009) Geochemical investigation

10-Karbasi, E and Bayati. A (2001) "Environmental Geochemistry", published byKavoshGhalam Publication, Tehran, Iran. Quaternary West Mashhad from Golestanport toKahou village) to measure toxic elements in soil and water ", Khorasan Regional Water Authority Research Committee).

11- Waste management master plan of the central area of Guilan: Waste Management Organization northern city of Rasht, Advisor: Science and Technology Park Gilan, Executive: Soil and Water Improvement Corporation, Rasht publishing, printing companies, advertising cultural ideas box art, 2010

12-Lee, G. F. and Jones, L, A. (2004). Flawed Technology of Subtitle D Landfilling of Municipal Solid Waste. Report of G. Fred Lee \& Associates, El Macero, CA, originally developed in 2004 (updated March) 
How to cite this article:

Geravand F, Momenpour M, Derakhshan Houreh M, Aghileh Hejazi Kamsari S. Investigating the effects of heavy metals in the waste leachate on the groundwater quality near the landfill (case study: landfill of saravan, rasht). J. Fundam. Appl. Sci., 2017, 9(1S), 484-499. 